\title{
Comparative feeding ecology of four syntopic Hypostomus species in a Brazilian southeastern river
}

\author{
G. A. Villares-Junior ${ }^{a *}$, I. B. Cardone ${ }^{a}$ and R. Goitein ${ }^{a}$

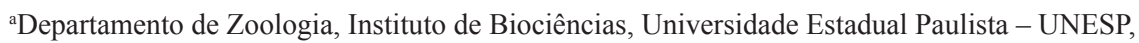 \\ Av. 24-A, 1515, CP 199, CEP 13506-900, Rio Claro, SP, Brazil \\ *e-mail: villaresjunior@hotmail.com
}

Received: January 12, 2015 - Accepted: May 8, 2015 - Distributed: August 31, 2016

(With 1 figure)

\begin{abstract}
Though their broad distribution in most Brazilian rivers, scarce studies concerning ecological interactions on Hypostomus species are available. This study observes the diet, the trophic interactions and some morphological aspects of four syntopic species of Hypostomus. These fishes were studied at the superior part of the Corumbataí river, at São Paulo state, southeastern Brazil. Analyses focused feeding patterns, their amplitude and whether there happens some food items overlap among the species. Fish were caught using cast nets at some points of the river. Species were chosen according to their local abundance and, so there were four main species: H. albopunctatus, H. ancistroides, H. regani and H. strigaticeps. Nine food items were found: sediments, fungi, diatoms, green algae, Tecamoeba, vegetal debris and invertebrates. There were not significant differences for the feeding pattern among the four Hypostomus species. The feeding niche amplitude has been larger for $H$. albopunctatus influenced by a larger amount of vegetal debris and invertebrates. Elevated niche overlap was found to happen among the species and also for their trophic morphology. Results may suggest that there is a similar pattern in food taken between four species of Hypostomus analyzed since all consume similar environmental resources and have similar anatomical features. However, a different intake insect larvae and plant material in H. albopunctatus diet indicate differences in local and how this species may be exploring their food compared to the others.
\end{abstract}

Keywords: Corumbataí river, niche breadth, niche overlap, macrohabitat.

\section{Ecologia alimentar comparativa de quatro espécies simpátricas de Hypostomus em um rio do sudoeste brasileiro}

\section{Resumo}

Apesar de sua grande distribuição em todos rios brasileiros, poucos estudos estão disponíveis sobre as interações ecológicas do gênero Hypostomus. Neste estudo nós examinamos a dieta, as interações tróficas e a morfologia de quatro espécies sintópicas de Hypostomus sp. no trecho superior do rio Corumbataí, estado de São Paulo no sudeste do Brasil. As análises focaram o padrão alimentar, a amplitude e sobreposição de nicho alimentar e a correlação entre a dieta com características da morfologia. A captura dos exemplares foi realizada com o uso de redes de arremesso (tarrafa) ao longo do leito do rio. O critério adotado para a escolha baseou-se nas espécies de maior abundância no local, chegando a quatros espécies principais: $H$. albopunctatus, $H$. ancistroides, $H$. regani e $H$. strigaticeps. Foram encontrados nove itens alimentares: sedimento grosso e fino, hifas de fungos, diatomáceas, algas verdes, algas azuis, Tecamoeba, restos de material vegetal e invertebrados, não havendo diferenças significativas no padrão alimentar entre as quatro espécies de Hypostomus. A amplitude de nicho alimentar foi maior para H. albopunctatus influenciada por um maior consumo de material vegetal e invertebrados. Foram encontrados altos valores de sobreposição de nicho alimentar além de uma similaridade entre a dieta e a morfologia trófica entre as espécies consideradas. Os resultados sugerem que exista um padrão semelhante na tomada de alimento entre as quatros espécies de Hypostomus analisadas, uma vez que, todas consomem recursos alimentares semelhantes e possuam características anatômicas semelhantes. No entanto, uma ingestão diferenciada de larvas de insetos e material vegetal na dieta de H. albopunctatus indicam diferenças nos locais e na forma como esta espécie pode estar explorando o seu alimento em comparação com as demais.

Palavras-chave: rio Corumbataí, amplitude de nicho, sobreposição de nicho, macrohabitat. 


\section{Introduction}

For ecological purposes it is important to evaluate which environmental conditions present limitations to communities (Cetra et al., 2011). According Rivas (1964) the term syntopic to be used in reference to two or more related species which occupy the same locality (macrohabitat). A diet analysis may reveal important information about the trophic dynamics and resource partitioning among fish species (Ross, 1986). The resource utilization patterns constitute a fundamental mark of the ecological systems (Winemiller and Pianka, 1990), in which the food resources partitioning among coexistent species plays a more important role than that described even for the habitat partitioning inside aquatic environments (Schoener, 1974; Ross, 1986). Such a division may occur both in an intraspecific level as in an interspecific one (Gerking, 1994), and is seen as one the basic causes of population and community structurations (Tofoli et al., 2010). On the other hand, coexisting species may present a niche division based on spatial or temporal scales (Correa et al., 2011). Mechanisms of living and interactions among species remain as a central theme for the populations ecology and niche differences have been evoked as fundamental to keep biodiversity in distinct scales (Leibold and McPeek, 2006).

An elevated trophic plasticity may permit fishes to fit their feeding habits to fluctuations of food availability (Balassa et al., 2004). The two stochastic processes and the abundance of some kinds of food may reduce an intraspecific competition, which may permit a better coexistence of species in a same place (Dias and Fialho, 2011; Uieda and Pinto, 2011). The species which are phylogenetically related may display ecologic similarities in diverse aspects; so, in this way, feeding data may subsidies factors that segregate sympatric species, and may inform some single ecologic questions, such as competition and food resource partitioning (Tofoli et al., 2010).

Other factors such as the trophic morphology, the use of distinct microhabitats, activity periods and feeding strategies may minimize overlapping effects (Casatti, 2002; Brazil-Sousa et al., 2009; Cetra et al., 2011). The use of morphologic attributes may reflect an integration of a broad variety of ecosystem influences to the organisms which live inside those systems, mainly for aquatic organisms and are suited to define morphologic and ecologic similar patterns (Winston, 1995). Such morphologic variations may have favored the coexistence of fish groups in diverse regions where they live. This may be due to spatial and temporal differences of their distributions, which may appear as distinct adaptations for the habitat placement and resource exploration, which may minimize some kinds of competition (Lagler et al., 1977). In fact, the ralationship between diet, body form and taxonomic aspects is commonly predicted for different levels in a community, which may adjust morphologic and ecologic configurations (Winston, 1995). Catella and Petrere Júnior (1998) believe that body form and feeding habits may reflect the general characteristics of the chemical and physical factors of the environment.
The Loricariidae represents a large group of fishes found primarily in freshwater ecosystems of the Neotropical Region (Nelson, 1994), and are known to constitute the world's most diverse family of catfishes. They are represented by six subfamilies, about 90 genera and a few more than 680 described species (Menezes et al., 2007). Individuals of this family present morphologic differences, such as dermal plates, mouth presenting sucking ventral lips, with were certainly important role for the evolutionary success of the Loricariidae (Schaefer and Lauder, 1986; Schaefer and Stewart, 1993). The Loricariidae display typical benthonic habits, living permanently near to the bottom where they use to grasp substrate algae or search for invertebrates (Britski et al., 1999). Notwithstanding this fact, ecologic studies concerning loricariids are important to better understand their singular radiation, and also to figure out the dynamics of nutritional patterns in distinct tropical systems (Flecker et al., 2002; Nonogaki et al., 2007).

Hypostomus represents the most diverse genus within this family (Weber, 2003; Hollanda Carvalho et al., 2010; Borba et al., 2013). The species of this genus live frequently in rapid flowing rivers and display a benthonic habit near to stony bottoms (Garavello and Garavello, 2004). Another aspect to distinguish Hypostomus from other Loricariidae is its distinguished ability to breathe atmospheric air. Their stomach walls are plenty of vessels which permit them to gas changing from the blood to the stomach internal space, when they swallow directly air from the surface (Armbruster, 1998). According to Val and Almeida-Val (1995), they may be classified as species to present an accessory breathing, and present this behavior specially when hypoxic conditions are happening.

There are relatively few feeding studies related to species of this genus. In spite of their large distribution in almost all Brazilian rivers there are important gaps in the comprehension of their ecologic interactions and also on morphological feeding aspects. Therefore, such ecological attributes should be better known to evaluate how they may explore feeding resources (Garavello and Garavello, 2004). In the present study we examine diet and trophic interactions of four sympatric species of Hypostomus from Corumbataí river in the São Paulo state in the southwestern of the Brazil. The analysis focuses in niche breadth, niche overlap between species and correlation of the diet with morphological features.

\section{Material and Methods}

The Corumbataí river basin is inserted in the Medium Tietê Peripheric Depression of the São Paulo State, at the northeastern portion of the sedimentary Paraná basin (Cetra, 2005), in which the Corumbataí is one of the most important affluent of the Piracicaba river. Collections were made monthly from June 2002 to May 2003. The collection site $\left(22^{\circ} 12^{\prime} 47^{\prime \prime} \mathrm{S}\right.$ and $\left.47^{\circ} 37^{\prime} 40^{\prime \prime} \mathrm{W}\right)$ locate near to an urban area of Corumbataí, at $25 \mathrm{~km}$ from the water spring (Figure 1). This river place locates up to the waste deposit coming from Corumbataí, which maintains the 


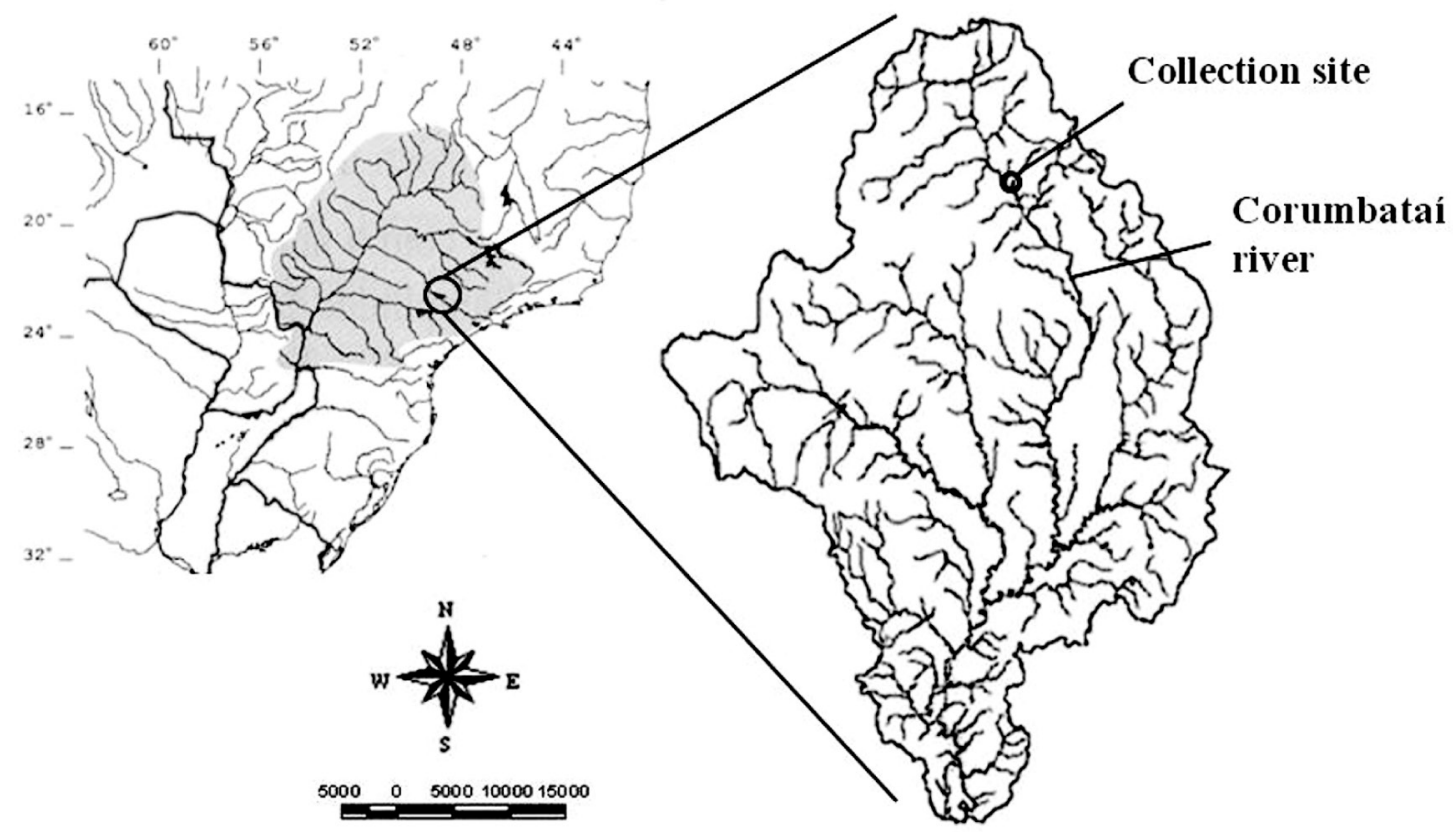

Figure 1. Partial map of South America showing the Alto Paraná river basin and location of Corumbataí river basin with localization of the collection site.

water condition almost unchanged (Lima Júnior, 2004; Cardone et al., 2006).

For the collections of specimens of Hypostomus sp. the employment of cast nets was used. This device measures 2 meters height and 1.2, 2.0 and $3.5 \mathrm{~cm}$ between the opposite meshes. It is a well suited method, as such fish use to move slowly. The caught individuals were separated in boxes containing ice, to be analyzed at the Zoology Department of UNESP - Rio Claro, SP. Identifications were based on Zoology Museum Prof. Heraldo Bristki and confirmed using Graça and Pavanelli (2007). So, four main species were identified: H. albopunctatus (Regan, 1908), H. ancistroides (Ihering, 1911), H. regani (Ihering, 1905) and $H$. strigaticeps (Regan, 1908). These were the most common species found in the system.

The diet analysis was made using stomach contents from the anterior third part of the gut, including the stomach, which contains normally the less digested material. The whole material for analysis was introduced in a graduated cylinder containing $70 \%$ ethanol filled until $50 \mathrm{~mL}$. From the homogenized contents standardized sub-samples were disposed on lamina for identification and counting of food items, which were identified to the lowest possible taxonomic level. The food importance based on those analyses was established based on the volumetric method (Hyslop, 1980). For the evaluation of the similarity of feeding patterns among the species a comparison of the volumetric frequencies was made by the one-way test ANOSIM (5\%) using the software PAST 2.15 (Hammer et al., 2001).
The volumetric proportions of respective data for each food item were joined for the calculation of the niche amplitude and feeding overlap. The niche amplitude has been calculated following the Lewis Index (Krebs, 1999), by using the Formula 1:

$$
B=1 /\left(\sum_{i=1}^{n} P i^{2}\right)
$$

where: B represents the niche breadth, Pi the volumetric proportion of the food item $i$ compounding the diet and $n$ is the total number of food items of the diet.

The diet similarity was calculated based on the niche overlap index of Pianka (1974) Formula 2:

$O_{j k}=\sum_{i=1}^{n} P_{i j} P_{i k} / \sqrt{\sqrt{\sum_{i=1}^{n} P_{i j}^{2} \sum_{i=1}^{n} P_{i k}^{2}}}$

where: Ojk is niche overlap between species $\mathrm{j}$ and $\mathrm{k}, \mathrm{Pij}$ is the proportion of the resource $i$ used by species $j$ and Pik is the proportion of resource $\mathrm{i}$ used by species $\mathrm{k}$ and $\mathrm{n}$ is the total number of resources categories.

There were measured nine morphologic attributes related to feeding: intestine length, jaw size, mouth width, head length, head height, body height, eye diameter, teeth number and gill rakers number. By using these morphometric data it was possible to build matrices using the Euclidian distance and a Mantel test of correlation was used to verify the distance of the morphology with the similar use of feeding resources. 


\section{Results}

A total number of 582 individuals was collected for this analysis, with the great majority being represented by $H$. strigaticeps. Within the stomach contents of the four armored catfishes were found nine food categories: coarse sediment, fine sediment mixed with organic matter, fungi hifa, diatom algae (Navicula, Pimularia, Nitzschia, Melosira and Synedra), green algae (Closterium, Cosmarium, Ankistrodesmus, Micrasterias, Scenedesmus, Oedogonium and Clorela), blue algae (Oscilatoria and Lyngbia), Tecamoeba shells; vegetal remains (parts of autochthonous and alochthonous plants) and invertebrates. The ANOSIM test did not reveal significant differences for the feeding pattern of individuals belonging to the four species during the period $(\mathrm{R}=1.167, \mathrm{p}>0.05)$.

The niche amplitude analyses for the four Hypostomus species showed the index to be larger for $H$. albopunctatus (Table 1) influenced by a higher consumption of plant material and invertebrate parts (Table 2).

During this period the Index of Pianka analyses presented niche high values of overlapping (up to 0.50) among those species, as the higher observed overlapping values occurred between $H$. regani and $H$. strigaticeps and between $H$. ancistroides and $H$. strigaticeps. The lowest overlapping value was, otherwise, observed between $H$. albopunctatus and $H$. ancistroides (Table 3 ).

The comparison result among the trophic similarity matrices and the trophic morphology, the Mantel test, indicated the existence of an interspecific significant correlation $(r=0.6532 ; p<0.05)$ among the diets and the morphometric attributes (Table 4) related to the feeding of the four Hypostomus species.

Table 1. Niche breadth of four species of Hypostomus from Corumbaí river.

\begin{tabular}{lcc}
\hline & $\mathbf{n}$ & $\mathbf{B}$ \\
\hline H. albopunctatus & 28 & 5.1203 \\
H. regani & 29 & 4.5475 \\
H. ancistroides & 21 & 3.7481 \\
H. strigaticeps & 504 & 3.9463 \\
\hline
\end{tabular}

$\mathrm{n}=$ numbers of individuals; $\mathrm{B}=$ niche breadth.

\section{Discussion}

The four studied species show that their food items are predominantly constituted by particulate organic material, and may suggest that all of them can be classified as detritivores. A similar pattern has been discussed to occur by Uieda (1984); Arcifa and Meschiatti (1993); Castro and Caramaschi (2003); Hahn et al. (2004); Casatti et al. (2005); Brandão-Gonçalves et al. (2010); Mazzoni et al. (2010); Silva et al. (2012), as an elevated consume of sediment and alloctonous and autochthonous organic matter mainly of vegetal material predominated. Instead of this, Delariva and Agostinho (2001) found a more varied diet, which could be classified as omnivore. This may reveal the existence of a relative plasticity for the feeding behavior of Hypostomus species (Buck and Sazima, 1995). Most species of this genus, however, do not use to select their food, by ingesting what is more available when they grasp the substrate (Delariva and Agostinho, 2001), which depends on ingesting a relative great amount of items to get a satisfactory energetic amount.

The lithologic constitution of the river may be related to this elevated consume of sediment, as the Corumbataí river uses to get an consistent deposition of sediment (Viadana, 1993). In an association to this fact, loricariids use to grasp the substrate, which contains the organic matter mixed to the sediment. In the South American systems there happens a clear dominance of fish species, which use to ingest a great amount of sediments and play the role of the basic consumers (Bowen, 1983; Fugi, 1993; Gerking, 1994). Detritivory is known to be a common feeding habit for Loricariidae species and relates to a morphologic adaptation of their digestive system, such as the mouth form and position and the length of the intestine, as well (Agostinho et al., 1997; Hahn et al., 1997). Their general aspect permits them to dwell and explore benthonic microhabitats, by grazing on the algae and the associated microfauna (Garavello and Garavello, 2004). Iliophagy is a similar way of feeding upon the substrate, but is commonly accepted for only some species, such as the Prochilodontidae and Curimatidae species, which use to ingest sediment to absorb the organic material from them. So, in spite of ingesting sediments, Loricariidae differ from other substrate feeders in neotropical waters.

Table 2. Volumetric percentage of food items of the four Hypostomus species from Corumbaí river.

\begin{tabular}{lcccc}
\hline & H. albopunctatus & H. regani & H. ancistroides & H. strigaticeps \\
\hline thick sediment & 22.35 & 21.44 & 22.49 & 25.13 \\
fine sediment & 24.86 & 35.12 & 3.059 & 39.66 \\
Diatoms & 11.11 & 17.00 & 16.08 & 11.95 \\
Hyphae & 9.20 & 11.06 & 10.65 & 11.89 \\
green algae & 2.87 & 4.62 & 5.74 & 4.95 \\
Tecamoebas & 1.91 & 2.01 & 6.74 & 4.64 \\
plant material & 25.09 & 8.38 & 7.69 & 1.31 \\
invertebrates & 2.59 & 0.00 & 0.00 & 0.05 \\
blue algae & 0.00 & 0.36 & 0.00 & 0.40 \\
\hline
\end{tabular}


In any case, such as iliophagous species, the Loricariidae also constitute and important part of the trophic web in these systems (Alvin and Peret, 2004), in respect of the whole fish fauna.

By statistically comparing the food items volumetric frequencies added to the elevated values for the feeding niche overlapping it may be observed homogeneity related to the whole consummation of food organisms. Some fish display definite diets in result of their anatomic and physiologic adaptations. On the other hand, the feeding efficiency may regard the subtle differences among species when they, in fact, exist. Fish relative sizes may also play some role to these aspects, but could not be perceived by these results. Loricariidae are known by their highly specialized way of living in rapid water streams, presenting depressed bodies, staying almost immobilized and using their suctorial discs around their mouths (Casatti and Castro, 2006; Ferreira, 2007).

The ingestion of Tecamoeba may also be related to a sediment swallowing, as such organisms use to be associated to such kind of sediment. This grazing and grasping of the substrate confirms that such species find their food on or inside the substrate (Ross, 1986). So, a similar resource may be available and partitioned by several species, though they may be able to explore other ones, as well (Hahn et al., 2004; Merona and Rankin-de-Merona, 2004; Novakowski et al., 2008).

Overlapping measurements may determine the resources segregation degree among the species, but may also furnish a descriptive measure of the population's organization (Correa et al., 2011). The higher abundance of $H$. strigaticeps in this system may also be another fact to explain the similarity between the diets of the Hypostomus species, in the high Corumbataí, as one may think that

Table 3. Niche overlap feeding $\left(0_{\mathrm{jk}}\right)$ between pair of four Hypostomus species from Corumbataí river.

\begin{tabular}{lc}
\hline & $\mathbf{0}_{\mathbf{j k}}$ \\
\hline H. albopunctauts $\times$ H. regani & 0.7778 \\
H. albopunctatus $\times$ H. ancistroides & 0.5983 \\
H. albopunctatus $\times$ H. strigaticeps & 0.7073 \\
H. regani $\times$ H. strigaticeps & 0.9700 \\
H. ancistroides $\times$ H. strigaticeps & 0.9740 \\
\hline
\end{tabular}

there may not exist any system, which should permit the abundance of several species belonging to a same genus, presenting such overlapping diets. This may suggest that some species may display a better ability in relation to the other ones by performing a broader distribution in a same area.

Though the existence of an elevated diet similarity among the species, a peculiarity presented by $H$. albopunctatus, which ingested more insects and vegetal material, represented mainly by dipterans (Simulidae), which use to occur in rapid streams fixed to rocks (Borror and Delong, 1964) very near to the margins (personal observation). This species may differ from the other ones by using its feeding site in distinct places, which is common to happen (Cabral, 2000). Distinct microhabitats may permit an easier coexistence between species (Declerky et al., 2002). In places where food overlapping uses to occur kinds of food and space may be recognized as the main axes as similar foods may occur in distinct microhabitats. Food and space are recognized as the main axes of resources to a niche division in vertebrates (Schoener, 1974), however Chase and Leibold (2003) state that related species living in a same community may present some type of differentiation (temporal or spatial) for the occupation of microhabitats. Some cases of spatial segregation of fishes presenting high overlapping indices for their feeding may occur as a consequence of historical differences between them in innate ability for habitat use and the absence of a species in a microhabitat (Edds et al., 2002). Differences of feeding tactics may lead during the evolutionary history of the species to a reduction of the effect for alimentary overlapping (Sabino and Correa e Castro, 1990). By considering that species belonging to a same genus use to show similarities in their general characters, Mazzoni et al. (2012) suppose that other characteristics which were not measured or perceived in this study may help to explain this feeding patterns and species coexistence.

The significant correlation between these similarities, both to the diets and the morphologic aspects, may play a particular role when such species are compared to the other ones belonging to the community (Labropoulou and Eleftheriou, 1997). So, these species do not present distinct specializations for their diets and trophic morphology. However, the higher abundance of $H$. strigaticeps suggest

Table 4. Median values of the nine morphological attributes of four Hypostomus species from Corumbataí river.

\begin{tabular}{lcccc}
\hline \multicolumn{1}{c}{ morphological attributes } & H. albopunctatus & H. regani & H. ancistroides & H. strigaticesps \\
\hline jaw length & 0.65 & 0.50 & 0.80 & 0.96 \\
intestine length & 127.10 & 169.85 & 193.80 & 187.5 \\
mouth length & 2.65 & 1.50 & 1.90 & 2.31 \\
body height & 2.75 & 1.80 & 2.20 & 2.1 \\
head length & 4.75 & 2.85 & 3.80 & 3.6 \\
eye diameter & 0.55 & 0.40 & 0.80 & 0.60 \\
head height & 2.1 & 1.60 & 1.80 & 1.80 \\
number of teeth & 43 & 32 & 65 & 83 \\
number of gill rakers & 65 & 43 & 60 & 59 \\
\hline
\end{tabular}


that this specie may display a better ability in relation to the other ones by performing a broader distribution in a same area and a different intake insect larvae and plant material in H. albopunctatus diet indicate differences in local and how this species may be exploring their food compared to the others species of Hypostomus in this lotic system.

\section{Acknowledgements}

We thank the teachers Luis Alberto Zavala-Camin, Heraldo Britski, Sidnei E. Lima Júnior for academic support and Brazilian agencies CAPES for their financial assistance.

\section{References}

AGOSTINHO, A.A., BINI, L.M. and GOMES, L.C., 1997. Ecologia de comunidades de peixes da área de influência do reservatório de Segredo. In: A.A. AGOSTINHO and L.C. GOMES. Reservatório de Segredo: bases ecológicas para o manejo. Maringá: EDUEM, pp. 97-112.

ALVIN, M C.C. and PERET, A.C., 2004. Food resource sustaining the fish fauna in a section of the Upper São Francisco River in the Três Marias, MG, Brazil. Brazilian Journal of Biology $=$ Revista Brasileira de Biologia, vol. 64, no. 2, pp. 195-202.

ARCIFA, M.S. and MESCHIATTI, A.J., 1993. Distribution and feeding ecology fishes in a Brazilian reservoir: lake Monte Alegre. Interciencia, vol. 18, no. 6, pp. 302-313.

ARMBRUSTER, J.W., 1998. Modifications of the digestive tract for holding air in loricariid and scoloplacid catfishes. Copeia, vol. 3, no. 3, pp. 663-675. http://dx.doi.org/10.2307/1447796.

BALASSA, G.C., FUGI, R., HAHN, N.S. and GALINA, A.B., 2004. Dieta de espécies de Anostomidae (Teleostei, Characiformes) na área de influência do reservatório de Manso, Mato Grosso, Brasil. Iheringia: Série Zoologia, vol. 94, pp. 77-82.

BORBA, R.S., ZAWADZKI, C.H., OLIVEIRA, C., PERDICES, A., PARISE-MALTEMPI, P.P. and ALVES, A.L., 2013. Phylogeography of Hypostomus strigaticeps (Siluriformes: Loricariidae) inferred by mitochondrial DNA reveals its distribution in the upper Paraná River basin. Neotropical Ichthyology, vol. 11, no. 1, pp. 111-116. http://dx.doi.org/10.1590/S1679-62252013000100013.

BORROR, D.J. and DELONG, D.M., 1964. Introdução ao estudo dos insetos. New York: Holt, Rinehart and Winston. 653 p.

BOWEN, S.H., 1983. Detritivory in neotropical communities. Environmental Biology of Fishes, vol. 9, no. 2, pp. 137-144. http://dx.doi.org/10.1007/BF00690858.

BRANDÃO-GONÇALVES, L., OLIVEIRA, S.A. and LIMAJUNIOR, S.E., 2010. Hábitos alimentares da ictiofauna do córrego Franco, Mato Grosso do Sul, Brasil. Biota Neotropica, vol. 10, no. 2, pp. 21-30. http://dx.doi.org/10.1590/S1676-06032010000200001.

BRAZIL-SOUSA, C., MARQUES, R.M. and ALBRECHT, M.P., 2009. Segregação alimentar entre duas espécies de Heptapteridae no Rio Macaé, RJ. Biota Neotropica, vol. 9, no. 3, pp. 31-37. http://dx.doi.org/10.1590/S1676-06032009000300002.

BRITSKI, H.A., SILIMON, K.Z.S. and LOPES, B.S., 1999. Peixes do Pantanal: manual de identificação. Brasília: Embrapa. 184 p.

BUCK, S. and SAZIMA, I., 1995. An assemblage of mailed catfishes (Loricariidae) in southeastern Brazil: distribution, activity, and feeding. Ichthyological Exploration of Freshwaters, vol. 6, no. 4, pp. 325-332.

CABRAL, H.N., 2000. Comparative feeding ecology of sympatric Solea solea and $S$. senegalensis, within the nursery areas of the Tagus estuary, Portugal. Journal of Fish Biology, vol. 57, no. 6, pp. 1550-1562. http://dx.doi.org/10.1111/j.1095-8649.2000.tb02231.x.

CARDONE, I.B., LIMA-JUNIOR, S.E. and GOITEIN, R., 2006. Diet and Capture of Hypostomus strigaticeps (SILURIFORMES, LORICARIIDAE) in a small Brazilian stream: relationship with limnlogical aspects. Brazilian Journal of Biology $=$ Revista Brasileira de Biologia, vol. 66, no. 1A, pp. 25-33. http://dx.doi. org/10.1590/S1519-69842006000100005. PMid:16680303.

CASATTI, L. and CASTRO, R.M.C., 2006. Testing the ecomorphological hypothesis in a headwater riffles fish assemblage of the rio São Francisco, southeastern Brazil. Neotropical Ichthyology, vol. 4, no. 2, pp. 203-214. http://dx.doi.org/10.1590/ S1679-62252006000200006.

CASATTI, L., 2002. Alimentação dos peixes em um riacho do Parque Estadual Morro do Diabo, Bacia do Alto Rio Paraná, sudeste do Brasil. Biota Neotropica, vol. 2, no. 2, pp. 1-14. http:// dx.doi.org/10.1590/S1676-06032002000200012.

CASATTI, L., ROCHA, F.C. and PEREIRA, D.C., 2005. Habitat use by two species of Hypostomus (Pisces, Loricariidae) in Southeastern Brazilian streams. Biota Neotropica, vol. 5, no. 2, pp. 1-9. http://dx.doi.org/10.1590/S1676-06032005000300012.

CASTRO, A L.M. and CARAMASCHI, E.P., 2003. Alimentação de Hypostomus emarginatus (Teleostei, Loricariidae) no Alto Rio Tocantis antes e após o represamento pela UHE Serra da Mesa, GO. Biociências, vol. 11, no. 1, pp. 23-30.

CATELLA, A.C. and PETRERE-JÚNIOR, M., 1998. Body-shape and food habits of fish from Baía da Onça, a Pantanal flood plain lake, Brazil. Verhandlungen des Internationalen Verein Limnologie, vol. 26, pp. 2203-2208.

CETRA, M., 2005. Caracterização das assembléias de peixes da Bacia do Rio Corumbatai (SP). Biota Neotropica, vol. 5, no. 1, pp. 219-220. http://dx.doi.org/10.1590/S1676-06032005000100029.

CETRA, M., RONDINELI, G.R. and SOUZA, U.P., 2011. Compartilhamento de recursos por duas espécies de peixes nectobentônicas de riachos na bacia do rio Cachoeira (BA). Biota Neotropica, vol. 11, no. 2, pp. 87-95. http://dx.doi.org/10.1590/ S1676-06032011000200010.

CHASE, J.M. and LEIBOLD, M.A., 2003. Ecological niches: linking classical and contemporary approaches. Chicago: University Chicago. 212 p. http://dx.doi.org/10.7208/chicago/9780226101811.001.0001.

CORRÊA, C.E., ALBRECHT, M.P. and HAHN, N.S., 2011. Patterns of niche breadth and feeding overlap of the fish fauna in the seasonal Brazilian Pantanal, Cuiabá River basin. Neotropical Ichthyology, vol. 9, no. 3, pp. 637-646. http://dx.doi.org/10.1590/ S1679-62252011000300017.

DECLERKY, S., LOUETTE, G., BIE, T. and MEESTER, L., 2002. Patterns of diet overlap between populations of non-indigenous and native fishes in shallow ponds. Journal of Fish Biology, vol. 61, no. 5, pp. 1182-1197. http://dx.doi.org/10.1111/j.1095-8649.2002. tb02464.x.

DELARIVA, R.L. and AGOSTINHO, A.A., 2001. Relationship between morphology and diets of six Neotropical loricariids. Journal of Fish Biology, vol. 58, no. 3, pp. 832-847. http://dx.doi. org/10.1111/j.1095-8649.2001.tb00534.x. 
DIAS, T.S. and FIALHO, C.B., 2011. Comparative dietary analysis of Eurycheilichthys pantherinus and Pareiorhaphis hystrix: two Loricariidae species (Ostariophysi, Siluriformes) from Campos Sulinos biome, southern Brazil. Iheringia. Série Zoologia, vol. 101, pp. 49-55.

EDDS, D.R., MATTHEWS, W.J. and GELWICK, F.P., 2002. Resource use by large catfishes in a reservoir: is there evidence for interactive segregation and innate differences? Journal of Fish Biology, vol. 60, no. 3, pp. 739-750. http://dx.doi. org/10.1111/j.1095-8649.2002.tb01698.x.

FERREIRA, K.M., 2007. Biology and ecomorphology of stream fishes from the rio Mogi-Guaçu basin, Southeastern Brazil. Neotropical Ichthyology, vol. 5, no. 3, pp. 311-326. http://dx.doi. org/10.1590/S1679-62252007000300012.

FLECKER, A.S., TAYLOR, B.W., BERNHARDT, S.E., HOOD, J.M., CORNWELL, W.K., CASSATT, S.R., VANNI, M.J. and ALTMAN, N.S., 2002. Interactions between herbivorous fishes and limiting nutrients in a tropical stream ecosystem. Ecology, vol. 83, no. 7, pp. 1831-1844. http://dx.doi.org/10.1890/00129658(2002)083[1831:IBHFAL]2.0.CO;2.

FUGI, R., 1993. Estratégias alimentares utilizadas por cinco espécies de peixes comedoras de fundo do alto Rio Paranál $P R$-MS. São Carlos: Universidade Federal de São Carlos, 142 p. Masters Dissertation.

GARAVELLO, J.C. and GARAVELLO, J.P., 2004. Spatial Distribution and interaction of four species of the catfish genus Hypostomus Lacépède with bottom of rio São Francisco, Canindé do São Francisco, Sergipe, Brazil (Pisces, Loricariidae, Hypostominae). Brazilian Journal of Biology $=$ Revista Brasileira de Biologia, vol. 64 , no. 3B, pp. 591-598. http://dx.doi.org/10.1590/S151969842004000400006. PMid:15619997.

GERKING, S.D., 1994. Feeding ecology of fishes. San Diego: Academic Press. 416 p.

GRAÇA, W.J. and PAVANELLI, C.S., 2007. Peixes da Planicie de Inundação do Alto Rio Paraná e áreas adjacentes. Maringá: EDUEM. $241 \mathrm{p}$

HAHN, N.S., ANDRIAN, I.F., FUGI, R. and ALMEIDA, V.L.L., 1997. Ecologia Trófica. In: A.E.A.M. VAZZOLER, A.A. AGOSTINHO and N.S. HAHN. A planície de inundação do alto Rio Paraná: aspectos físicos, biológicos e socioeconômicos. Maringá: EDUEM, pp. 209-228.

HAHN, N.S., FUGI, R., LOUREIRO-CRIPPA, V.E., PERETTI, D. and RUSSO, M.R., 2004. Trophic structure of the fish fauna. In: A.A. AGOSTINHO, L. RODRIGUES, L.C. GOMES, S.M. THOMAZ and L.E. MIRANDA. Structure and functioning of the Paraná River and its floodplain. Maringá: EDUEM, pp. 139-143.

HAMMER, Ø., HARPER, D.A.T. and RYAN, P.D., 2001 [viewed 12 January 2015]. PAST: paleontological statistics software package for education and data analysis. Palaeontologia Electronica [online], vol. 4, no. 1, pp. 1-9. Available from: http://palaeo-electronica. org/2001_1/past/issue1_01.htm

HOLLANDA CARVALHO, P., LIMA, F.C.T. and ZAWADZKI, C.H., 2010. Two new species of the Hypostomus cochliodon group (Siluriformes: Loricariidae) from the rio Negro basin in Brazil. Neotropical Ichthyology, vol. 8, pp. 39-48.

HYSLOP, E.J., 1980. Stomach content analysis: a review of methods and their applications. Journal of Fish Biology, vol. 17, no. 4, pp. 411-429. http://dx.doi.org/10.1111/j.1095-8649.1980.tb02775.x.
KREBS, C.J., 1999. Ecological methodology. 2nd ed. New York: Benjamin Cummings. 620 p.

LABROPOULOU, M. and ELEFTHERIOU, A., 1997. The foraging ecology of two pairs of congeneric demersal fish species: importance of morphological characteristics in prey selection. Journal of Fish Biology, vol. 50, no. 2, pp. 324-340. http://dx.doi. org/10.1111/j.1095-8649.1997.tb01361.x.

LAGLER, K.F., BARDACH, J.E., MILLER, R.R. and PASSINO, D.R.M., 1977. Ichthyology. 2nd ed. New Yourk: John Wiley \& Sons. 528 p.

LEIBOLD, M.A. and MCPEEK, M.A., 2006. Coexistence of the niche and neutral perspectives in community ecology. Ecology, vol. 87, no. 6, pp. 1399-1410. http://dx.doi.org/10.1890/00129658(2006)87[1399:COTNAN]2.0.CO;2. PMid:16869414.

LIMA-JUNIOR, S.E., 2004. A ictiofauna e a qualidade da água em trechos do Rio Corumbatai - SP. Rio Claro: Universidade Estadual Paulista, 232 p. PhD Thesis.

MAZZONI, R., MARQUES, P.S., REZENDE, C.F. and IGLESIASRIOS, R., 2012. Niche enlargement as a consequence of co-existence: a case study. Brazilian Journal of Biology $=$ Revista Brasileira de Biologia, vol. 72, no. 2, pp. 267-274. http://dx.doi.org/10.1590/ S1519-69842012000200006. PMid:22735133.

MAZZONI, R., REZENDE, C.F. and MANNA, L.R., 2010. Feeding ecology of Hypostomus punctatus Valenciennes, 1840 (Osteichthyes, Loricariidae) in a costal stream from Southeast Brazil. Brazilian Journal of Biology $=$ Revista Brasileira de Biologia, vol. 70, no. 3, pp. 569-574. http://dx.doi.org/10.1590/ S1519-69842010000300013. PMid:20730343.

MENEZES, N.A., WEITZMAN, S.H., OYAKAWA, O.T. and LIMA, F.C.T., CASTRO, R.M.C. and WEITZMAN, M.J., 2007. Peixes de água doce da Mata Atlântica: lista preliminar das espécies a comentários sobre conservação de peixes de água doce neotropicais. São Paulo: Museu de Zoologia, Universidade de São Paulo. 408 p

MÉRONA, B. and RANKIN-DE-MÉRONA, J., 2004. Food resource partitioning in a fish community of the central Amazon floodplain. Neotropical Ichthyology, vol. 2, no. 2, pp. 75-84. http:// dx.doi.org/10.1590/S1679-62252004000200004.

NELSON, J.S., 1994. Fishes of the World. 3th ed. New York: John Wiley \& Sons. 600 p.

NONOGAKI, H., NELSON, J.A. and PATTERSON, W.P., 2007. Dietary histories of herbivorous loricariid catfishes: evidence from d13C values of otoliths. Environmental Biology of Fishes, vol. 78, no. 1, pp. 13-21. http://dx.doi.org/10.1007/s10641-006-9074-8.

NOVAKOWSKI, G.C., HAHN, N.S. and FUGI, R., 2008. Diet seasonality and food overlap of the fish assemblage in a Pantanal pond. Neotropical Ichthyology, vol. 6, no. 4, pp. 567-576. http:// dx.doi.org/10.1590/S1679-62252008000400004.

PIANKA, E.R., 1974. Niche overlap and diffuse competition. Proceedings of the National Academy of Sciences of the United States of America, vol. 71, no. 5, pp. 2141-2145. http://dx.doi. org/10.1073/pnas.71.5.2141. PMid:4525324.

RIVAS, L.R., 1964. A reinterpretation of the concepts "Sympatric" and Allopatric" with proposal of the additional terns "Syntopic" and Allotopic. Systematic Zoology, vol. 13, no. 1, pp. 42-43. http://dx.doi.org/10.2307/2411436. 
ROSS, S.T., 1986. Resource partitioning in fish assemblages: a review of field studies. Copeia, vol. 2, no. 2, pp. 352-388. http:// dx.doi.org/10.2307/1444996.

SABINO, J. and CORRÊA E CASTRO, R.M., 1990. Alimentação, período de atividade e distribuição espacial dos peixes de um riacho da floresta Atlântica (sudeste do Brasil). Brazilian Journal of Biology = Revista Brasileira de Biologia, vol. 50, pp. 23-36.

SCHAEFER, S.A. and LAUDER, G.V., 1986. Historical transformation of functional design: evolutionary morphology of feeding mechanisms in loricarioid catfishes. Systematic Zoology, vol. 35, no. 4, pp. 489-508. http://dx.doi.org/10.2307/2413111

SCHAEFER, S.A. and STEWART, D.J., 1993. Systematics of the Panaque dentex species group (Siluriformes: Loricariidae), wood-eating armored catfishes from tropical South America. Ichthyological Exploration of Freshwaters, vol. 4, pp. 309-342.

SCHOENER, T.W., 1974. Resource partitioning in ecological communities. Science, vol. 185, no. 4145, pp. 27-39. http://dx.doi. org/10.1126/science.185.4145.27. PMid:17779277.

SILVA, J.C., DELARIVA, R.L. and BONATO, K.O., 2012. Food-resource partitioning among fish species from a first-order stream in northwestern Paraná, Brazil. Neotropical Ichthyology, vol. 10 , no. 2 , pp. 389-399. http://dx.doi.org/10.1590/S167962252012005000008 .

TÓFOLI, R.M., HAHN, N.S., ALVES, G.H.Z. and NOVAKOWSKI, G.C., 2010. Uso do alimento por duas espécies simpátricas de Moenkhausia (Characiformes, Characidae) em um riacho da Região Centro-Oeste do Brasil. Iheringia: Série Zoologia, vol. 100, no. 3, pp. 201-206.
UIEDA, V.S. and PINTO, T.L.F., 2011. Feeding selectivity of ichthyofauna in a tropical stream: space-time variations in trophic plasticity. Community Ecology, vol. 12, no. 1, pp. 31-39. http:// dx.doi.org/10.1556/ComEc.12.2011.1.5.

UIEDA, V.S., 1984. Ocorrência e distribuição dos peixes e um riacho de agua doce. Revista Brasileira de Biologia $=$. Brazilian Journal of Biology $=$ Revista Brasileira de Biologia, vol. 44, pp. 203-213.

VAL, A.L. and ALMEIDA-VAL, V.M.F., 1995. Fishes of the Amazon and their environment: physiological and biochemical aspect. New York: Springer-Verlag. 224 p... http://dx.doi. org/10.1007/978-3-642-79229-8.

VIADANA, A.G., 1993. Perfis ictiobiogeográficos da Bacia do Rio Corumbatai (SP). São Paulo: Universidade de São Paulo, 119 p. PhD Thesis.

WEBER, C., 2003. Subfamily Hypostominae (Armored catfishes). In: R.E. REIS, S.O. KULLANDER and C.J. FERRARIS-JÚNIOR. Check list of the freshwater fishes of South America. Porto Alegre: EdiPUCRS, pp. 351-372.

WINEMILLER, K.O. and PIANKA, E.R., 1990. Organization in natural assemblages of desert lizards and tropical fishes. Ecological Monographs, vol. 60, no. 1, pp. 27-55. http://dx.doi. org/10.2307/1943025.

WINSTON, M.R., 1995. Co-occurrence of morphologically similar species of stream fishes. American Naturalist, vol. 145, no. 4, pp. 527-545. http://dx.doi.org/10.1086/285754. 